\title{
Pengaruh Aliran-Aliran Falsafat Pemidanaan dalam Pembentukan Hukum Pidana Nasional
}

\author{
Syaiful Bakhri \\ Fakultas Hukum Universitas Muhammadiyah Jakarta \\ Jl. K.H.Ahmad Dahlan, Jakarta. \\ bakhri_msb@yahoo.com.
}

\begin{abstract}
This research discusses the development of criminal sanction philosophy from time to time. This research is a normative research which has juridical philosophic character. The approach applied in this research is conceptual approach, because of its relation with criminal sanction philosophy which could be the basis of criminal law. The research was performed by using literary study. The legal matters is qualitatively analyzed. Using that method, the conclusions obtained are school of criminal law which developed in its era had influenced the Indonesian criminal legal scholar in formulating and connecting the theoretical framework and the criminal sanction philosophy inside the currently discussed reformation of criminal law either legislation or formal criminal law and material criminal law. School and philosophy of criminal law sanction has the role of reflection of Indonesian criminal law reformation.
\end{abstract}

Key words: The schools of criminal law, philosophy of punishment, national criminal law

\begin{abstract}
Abstrak
Penelitian ini membahas perkembangan falsafah pemidanaan dari masa ke masa ke masa. Penelitian ini adalah penelitian normatif yang bersifat yuridis filosofis. Pendekatannya adalah pendekatan konseptual, karena berkaitan dengan falsafah pemidanaan yang dapat menjadi dasar hukum pidana. Penelitian dilakukan dengan studi kepustakaan Kemudian bahan-bahan hukum yang ada dianalisis secara kualitatif. Dengan metode yang demikian didapatkan simpulan bahwa beberapa aliran hukum pidana, yang berkembang pada masanya, telah mempengaruhi para ahli hukum pidana Indonesia, ketika merumuskan, mengkaitkan landasan teori dan falsafah pemidanaan, dalam kancah pembaharuan hukum pidana, baik melalui pembaharuan perundangundangan maupun hukum pidana formal dan materil, yang sedang dalam pembahasannya. Aliran dan falsafah pemidanaan bersikap sebagai alat potret pembaharuan hukum pidana Indonesia.
\end{abstract}

Kata kunci : Aliran hukum pidana, falsafah pemidanaan, hukum pidana nasional 


\section{Pendahuluan.}

Pengenaan derita atau sanksi pidana, sudah dikenal sejak lama, dan dianggap terberi oleh masyarakat manapun. Dikaitkan dengan fakta, dalam hukum pidana, maka masyarakat tidak mungkin dapat berjalan, tanpa ikut campurnya hukum pidana. ${ }^{1}$ Pemidanaan bukan merupakan hal yang menyenangkan bagi seseorang yang dipidana. Pemidanaan menghabiskan biaya yang relatif banyak, biaya proses dalam pengadilan, penjara, pembebasan bersyarat, pusat-pusat konsultasi yang harus dihadiri, dan pengumpulan denda. Menurut teori utilitarian, pemidanaan merupakan kejahatan (mischief) yang hanya dapat dijustifikasi jika kejahatan tersebut mampu mencegah terjadinya kejahatan yang lebih besar dibandingkan dengan pemidanaan bagi pelaku kejahatan. ${ }^{2}$

Pemikiran pemikiran yang mewarnai cita rasa keadilan dalam pemidanaan memunculkan berbagai tujuan pemidanaan yang berkembang dari masa lalu hingga kini yang lebih mengarah ke arah yang lebih rasional. Dimulai dari teori pembalasan bertujuan untuk memuaskan semua pihak. Teori pembalasan hukum pidana, bersifat sangat primitif tetapi masih dirasakan pengaruhnya pada zaman modern, karena unsur primitif dalam hukum pidana paling sukar untuk dihilangkan. Berbeda dengan cabang hukum lainnya, tujuan yang dipandang kuno, yaitu penghapusan dosa (expiation) atau retribusi (retribution). ${ }^{3}$ Penderitaan pidana merupakan penebusan dosa dari si pembuat, dan kesalahannya akan dipulihkan melalui keseimbangan nilai pada diri si pembuat, serta merupakan kebutuhan fundamental dari sifat moral kita. ${ }^{4}$ Pada akhir abad kedelapan belas, dalam praktik hukum pidana, masih juga dipengaruhi oleh ide pembalasan yang secara bersama-sama dengan usaha menakutnakuti telah dipandang sebagai tujuan dari pemidanaan.

Sejak zaman klasik tujuan pemidanaan itu telah menjadi perhatian. Simons dengan mengikuti pandangan Immanuel Kant ${ }^{5}$, mengemukakan bahwa perbuatan

\footnotetext{
${ }^{1}$ Jan Remmelink, Hukum Pidana: Komentar Atas Pasal Pasal Terpenting dari KUHP Belanda dan Padanannya Dalam KUHP Indonesia, PT. Gramedia Pustaka Utama, Jakarta, 2003, hlm. 595.

${ }^{2}$ Barbara A. Hudson, Understanding Justice: an Introduction to Ideas, Perspectives and Controversies in Modern Penal Theory, Second Edition, Open University Press, Great Britain 2003, hlm, 17-18.

${ }^{3}$ Andi Hamzah, Sistem Pidana dan Pemidanaan dari Retribusi ke Reformasi, Pradnya Paramita, Jakarta 1986, hlm. 16.

${ }^{4}$ Barda Nawawi Arief, Kebijaksanaan Legislatif Mengenai Penetapan Pidana Penjara Dalam Rangka Usaha Penanggulangan Kejahatan, Disertasi Doktor di Universitas Padjadjaran Bandung, 1985. hlm 159.

${ }^{5}$ Pandangan Imanuel Kant, Pembenaran pidana, bersesuaian dengan kesadaran masyarakat, yang umumnya bersepakat, bahwa siapa yang mengibarkan penderitaan, maka harus menderita. Syarat mutlak pidana adalah pembalasan dengan suatu pemidanaan,karena kejahatan merupakan pengingkaran terhadap realitas, maka negara berfungsi menyelesaikannya.
} 
melanggar hukum yang telah terjadi itu mendapat pembalasan. Demikian juga Hegel, ${ }^{6}$ mengemukakan bahwa perbuatan melanggar hukum merupakan perbuatan yang tidak manusiawi. Hukum itu adalah pembalasan. Stahl mengemukakan bahwa asas pembalasan bersumber pada ketuhanan dan merupakan undang-undang yang bersifat abadi. Kejahatan harus dibalas oleh negara dan harus menderitakan pelakunya. Selanjutnya Von Bar dalam hal pemidanaan, mengemukakan hukum harus mendapatkan sifat kesusilaan yang dikehendaki oleh moral, tetapi dengan peradaban yang semakin maju, maka bentuk-bentuknya harus semakin luas. ${ }^{7}$ Sebagai peletak dasar aliran retributif, Immanuel Kant selalu berpangkal tolak bahwa pengenaan pidana atau pemidanaan adalah membalas perbuatan pelaku. Pemikiran Kant selanjutnya diikuti oleh para ahli lainnya dalam berbagai teori pembalasan. ${ }^{8}$ Pidana adalah tuntutan keadilan. Pidana sebagai suatu keharusan logis sebagai konsekuensi dari kejahatan, karena kejahatan adalah suatu pengingkaran terhadap ketertiban hukum dan negara yang merupakan perwujudan dari cita susila. ${ }^{9}$

Pada masa lalu, pidana yang sangat kejam adalah suatu manifestasi dicelanya oleh masyarakat maupun penguasa. Oleh karenanya pidana atau hukuman merupakan hak yang terpenting dalam hukum pidana. Sekarang sanksi pidana dijatuhkan oleh penguasa untuk suatu pembalasan terhadap pelaku yang melanggar suatu aturan, sehingga sanksi pidana dimaksudkan, sebagai upaya menjaga ketentraman dan kontrol dari masyarakat sebagai prevensi umum dan khusus. ${ }^{10}$ Mengenai tujuan yang ingin dicapai dalam suatu pemidanaan, ternyata tidak terdapat suatu kesamaan pendapat diantara para ahli, tetapi setidaknya ada tiga pokok pemikiran tentang tujuan yang hendak dicapai dalam suatu pemidanaan. Hal yang sama juga dapat diketahui dari para penulis bangsa Romawi, yakni, untuk memperbaiki pribadi diri penjahat itu sendiri, untuk membuat orang menjadi jera untuk melakukan kejahatan, dan untuk membuat penjahat-penjahat tertentu tidak

${ }^{6}$ Pandangan Hegel, bertolak pada konsekuensi logikal, sehingga negara dapat menjatuhkan pidana, dan manusia yang melakukan kejahatan sebagai mahkluk sosial yang dikarunia akal, mampu, bertanggung. jawab

${ }^{7}$ Simons, Kitab Pelajaran Hukum Pidana, Terjemahan P.A.F. Lamintang, Pioneer Jaya, Bandung, 1981, hlm. 7-8.

${ }^{8}$ Chairul Huda, Dari Tiada Pidana Tanpa Kesalahan Menuju Kepada Pertanggungjawaban Pidana Tanpa Kesalahan, Prenata Media, Jakarta, 2006, hlm. 128-129.

${ }^{9}$ Nyoman Serikat Putra Jaya, Relevansi Hukum Pidana Adat Dalam Pembaharuan Hukum Pidana, PT. Citra Aditya Bhakti, Bandung, 2005, hlm. 71. Dikemukakan juga bahwa setiap pidana adalah pembalasan, dengan anggapan agar orang lain harus dibuat takut (pencegahan umum dan pencegahan khusus). Lihat juga R.M Dworkin, Filsafat Moral Sebuah Pengantar, penterjemah Yudi Santoso, Yogyakarta, 2007, hlm. 28, dengan mengutip Austin dan Bentham, bahwa jika hukum mencapai derajat ketidakadilan tertentu maka akan terdapat kewajiban moral yang menentangnya dan memaksakan sebuah kepatuhan.

${ }^{10}$ Jan Remmelink, Op. Cit., hlm. 458. 
mampu untuk melakukan kejahatan lain, para penjahat yang dengan cara-cara lain, sudah tidak dapat diperbaiki lagi. ${ }^{11}$

\section{Rumusan Masalah}

Pokok persoalan dalam tulisan ini adalah bagaimana pengaruh aliran-aliran hukum pidana dalam perkembangan pembaharuan hukum pidana nasional.

\section{Tujuan Penelitian}

Penelitian ini bertujuan untuk mendapat pemahaman yang lebih mendalam, tentang pengaruh aliran-aliran hukum pidana dalam perkembangan pembaharuan hukum pidana nasional.

\section{Metode Penelitian}

Metode yang digunakan dalam penelitian ini adalah yuridis normatif yang bersifat filosofis. Kajian filosofis ditujukan terhadap permasalahan pemidanaan dengan pandangan falsafah pemidanaan. Bahan-bahan hukum yang diperlukan berupa bahan hukum primer dan sekunder. Bahan-bahan hukum tersebut dikumpulkan melalui studi kepustakaan secara mendalam. Selanjutnya bahanbahan hukum tersebut dianalisis secaya kualitatif. Teknik analisis ini dipakai mengingat penelitian ini bersifat yuridis normatif yang bersifat filosofis, tentu tidak mementingkan kuantitas, tetapi memerlukan kedalaman dan holitistik.

\section{Hasil dan Pembahasan.}

Perdebatan mengenai pemidanaan dan tujuan yang hendak dicapai, dalam hukum pidana secara ideal terus menerus mengalami penjelajahan untuk terus mencari ketajaman, baik secara sosiologis, politis maupun filosofis, untuk mencapai landasan bagi penerapan sanksi, dari berbagai alternatif pemidanaan yang lebih adil, untuk tercapainya keadilan sosial bagi masyarakat Indonesia, dalam perspektif Pancasila. Pemakaian Pancasila sebagai perspektif Indonesia, dalam pemidanaan, bertolak dari asumsi, bahwa sila-sila Pancasila memberi peluang untuk merumuskan

\footnotetext{
${ }^{11}$ P.A.F Lamintang, Hukum Penitensier Indonesia, Armico, Bandung, 1989, hlm. 10-11.
} 
apa yang benar dan yang baik, bagi manusia secara universal. Pancasila merumuskan asas atau hakikat abstrak kehidupan manusia Indonesia yang berpangkal pada tiga hubungan kodrat manusia selengkap-lengkapnya Sila pertama, sebagai kerangka ontologis yaitu manusia yang mengimani kekuasaan Tuhan Yang Maha Esa, sehingga mempunyai pegangan untuk menentukan kebaikan dan keburukan. Sila kedua, memberi kerangka normatif, karena berisi keharusan untuk bertindak adil dan beradab. Sila ketiga sebagai kerangka operasional, menggariskan batas-batas kepentingan individu, kepentingan negara dan bangsa. Sila keempat, tentang kehidupan bernegara, yakni pengendalian diri terhadap hukum, konstitusi dan demokrasi. Sila kelima, memberikan arah setiap individu untuk menjunjung tinggi keadilan, bersama orang lain dan seluruh warga masyarakat. Dengan demikian prinsip sila-sila Pancasila terkait secara timbal balik, satu dengan yang lain, yang terarah dan tersusun, serta seimbang dalam masalah pemidanaan yang berspektif Pancasila. $^{12}$

Dilihat dari kedudukan Pancasila dalam pembukaan Undang Undang Dasar 1945, maka pengertian groundnorm, akan mencakup hal-hal yang lebih luas, yakni memperhatikan penempatan Pancasila, tidak hanya sebagai norma hukum, tetapi dari seluruh norma-norma kehidupan bangsa Indonesia, termasuk norma etik dan moral. Sehingga Pancasila sebagai suatu norma dasar bagi kehidupan bangsa, masyarakat dan negara Indonesia. Pancasila mengharuskan tertib hukum, yang serasi dengan norma-norma moral dan kesusilaan. ${ }^{13}$ Pada masa Yunani, para filosofnya, telah membahas masalah maksud dan tujuan hukum pidana, dan alasan pembenarnya. Selanjutnya pada abad pertengahan, dan memasuki abad kedelapanbelas dan abad kesembilanbelas, diperbincangkan lebih mendalam, terutama di Jerman. Teori-teori kehendak hukum kodrat dan perjanjian. Selanjutnya teori-teori absolut, yang dikemukakan oleh Imanuel Kant dan Hegel, dengan keyakinan mutlak akan keniscayaan pidana, dalam hal kejahatan, maka negara mendapatkan pembenaran untuk menjatuhkan pidana. Teori-teori relatif. Mengajarkan bahwa pidana dipandang sebagai upaya atau sarana pembelaan diri. ${ }^{14}$ Perkembangan pemidanaan pada masa lalu melahirkan pemikiran baru tentang dasar pemidanaan pada akhir abad kesembilan belas dan permulaan abad

\footnotetext{
${ }^{12}$ Syaiful Bakhri, Pidana Denda dan Korupsi, Total Media, Yogyakarta, 2009, hlm. 136-137.

${ }^{13}$ Roeslan Saleh, Pembinaan Cita Hukum dan Asas-asas Hukum Nasional, Karya Dunia Fikir, Jakarta, 1995, hlm. 31-33.

${ }^{14}$ Jan Remmelink, Op. Cit., hlm. 600-610.
} 
keduapuluh. Pemikiran baru ini muncul di Eropa Barat yang dipelopori A. Prins (Belgia), G.A Van Hammel (Netherland), F. Von List (Jerman). Pada 1888 mereka mendirikan Union Internationale de Droit Penale. Sebelumnya di Belanda (1886), setelah KUHP (WvS) terjadi suatu gerakan menuju kemenangan rasional kriminalitas dengan mempergunakan hasil pemikiran baru yang diperoleh dari sosiologi, antropologi dan psikologi. Dengan pokok-pokok pikiran sebagai berikut: Pertama, tujuan pokok hukum pidana adalah pertentangan terhadap perbuatan jahat dipandang sebagai gejala masyarakat; Kedua, pengetahuan hukum pidana dan perundang-undangan pidana memperhatikan hasil studi antropologi dan sosiologi; Ketiga, pidana merupakan salah satu alat ampuh yang dikuasai negara dalam penentangan kejahatan, dan bukan satu-satunya alat, tidak dapat diterapkan tersendiri, tetapi dengan kombinasi, melalui tindakan sosial, khususnya kombinasi dengan tindakan preventif. ${ }^{15}$ Pembuat undang-undang bertugas untuk menetapkan apa yang diancam dengan pidana dalam bahasa yang mudah dimengerti, dan menghilangkan apa yang tidak jelas dalam undang-undang.

Beccaria mengemukakan bahwa dalam mengadili setiap kejahatan hakim harus menarik kesimpulan dari dua pertimbangan, yang pertama dibentuk oleh undangundang dengan batas berlakunya dan yang kedua adalah apakah perbuatan konkrit yang akan diadili itu bertentangan dengan undang-undang. ${ }^{16}$ Ketika itu hakim tidak leluasa untuk menuangkan pandangan dalam putusannya dan tidak dapat menafsirkan hukum. Hakim hanya mematuhi dan menerapkan kitab undangundang. Hal ini yang oleh para ahli hukum dilihat bahwa, pembentukan hukum semata-mata melalui pembentukan undang-undang dan tidak ada lembaga lain yang berwenang untuk itu. Dengan dimonopolinya pembentukan hukum oleh pembentuk undang-undang, maka sekurang-kurangnya dalam teori tidaklah ada lagi ruang bergerak dan berkarya bagi petugas hukum. Hakim pun dalam kemungkinan-kemungkinannya menafsirkan undang-undang itu seakan-akan diprogramkan. ${ }^{17}$

Dalam sistem monarki, para pejabat peradilan dan hakim hanya berfungsi untuk mengawasi kesewenang-wenangan dari kekuasaan. Hal ini telah mendapatkan pengakuan sejak lama berlangsung. Pada masa kekuasaan monarki menjamin

\footnotetext{
${ }^{15}$ Andi Hamzah, Sistem Pidana dan Pemidanaan dari Retribusi ke Reformasi, Op. Cit., hlm. 258

${ }^{16}$ J.M. Van Bammelen, Hukum Pidana II, Bina Cipta, Bandung, 1991, hlm 1.

${ }^{17}$ Roeslan Saleh, Penjabaran Pancasila dan Undang-Undang Dasar 1945 dalam Perundang-Undangan, Aksara Baru, Jakarta, 1979, hlm. 24.
} 
berlakunya hukum lama dan membentuk hukum baru, sehingga code civil Perancis disusun bukanlah atas dasar tindakan kekuasaan semata-mata, tetapi juga adalah merupakan tindakan dan kebijaksanaan, keadilan dan suatu tindakan yang beralasan. ${ }^{18}$

\section{Aliran Klasik Peranannya terhadap Pemidanaan Modern}

Kodifikasi hukum pidana pada masa klasik merupakan suatu kenyataan dari hasil ajaran hukum, asas-asas hukum dan sistematikanya dikerjakan oleh para ahli hukum di berbagai universitas, kemudian diserahkan kepada lembaga berwenang hingga menjadi bahan-bahan para pembuat undang-undang untuk menyusunnya secara rasional. Max Weber menyatakan bahwa sangatlah jelas dengan adanya pengaruh tertentu dari ahli hukum terhadap bentuk dan penalaran hukum, di Eropa Kontinental dominasi para ahli hukum terhadap hukum modern menjadikan aliran hukum dari universitas untuk mendidik para calon sarjana-sarjana hukum untuk berpikir mengenai hukum dalam pengertian abstrak dan menghubungkannya dengan berbagai konsep. Ciri utama dari aliran klasik, yang selama lebih dari satu abad menguasai ilmu hukum pidana dan meletakkan dasar bagi banyak hukum pidana yang berlaku, yaitu sifat dari aliran ini yang paling tepat adalah perkataan abstrak. $^{19}$

Aliran klasik yang dibangun oleh Beccaria membentangkan akhir dari zaman sistem pemerintahan kuno sekaligus juga menyusun rencana untuk zaman yang akan datang. Beccaria yang berhasil menyusun suatu konsep hukum kriminal yang lengkap yang lahir dari buah pikiran liberalisme yang sedang berkembang. ${ }^{20}$ Beccaria dipengaruhi oleh mazhab hukum alam yang berkembang pada masa itu yang mencari dasar pemidanaan dalam pengertian hukum yang berlaku umum. Negara adalah suatu penjelmaan kehendak manusia yang telah menjadi dasar pembenaran dari pemidanaan pada kehendak individu. Hugo de Groot yang menggunakan penjelasan tentang sebab akibat menyatakan bahwa seorang pelaku itu harus dipandang sebagai layak untuk menerima akibat dari perbuatannya telah melihat pada kehendak alam. Para pengikut mahzab hukum alam, kemudian mencari dasar

\footnotetext{
${ }^{18}$ A.G Peters.Antonie, Main Currents In Criminal Law Theory. Dalam Jan Van Dijk ed, Criminal Law In Action; An Overview of Currecnts Issues In Western Societie, Kluwer Law and Taxation Publisher, London 1996, hlm. 22.

${ }^{19}$ Roeslan Saleh, Dari Lembaran Kepustakaan Hukum Pidana, Sinar Grafika, Jakarta, 1988, hlm. 92.

${ }^{20}$ Van Bemmelen, Op. Cit., hlm. 2.
} 
pembenaran dari suatu pidana pada asas-asas hukum yang berlaku umum. Thomas Hobbes sebagai pendukung utilitarian berpandangan bahwa hukum adalah perintah penguasa. Oleh karenanya, hukum alam berupa keadilan, kesetaraan, kerendahan hati, tanpa paksaan dari penguasa, menyebabkan tidak adanya keteraturan. Hukum yang dibuat oleh penguasa adalah aturan perundangan yang berkaitan dengan pertimbangan manfaat kedamaian dan keamanan publik. ${ }^{21}$ Beccaria mencari dasar pembenarannya pada kehendak yang bebas warga negara, yakni yang telah mengorbankan sebagian kecil dari kebebasannya kepada negara, agar mereka dengan memperoleh perlindungan dari negara dapat menikmati sebagian besar dari kebebasan-kebebasannya. ${ }^{22}$

Hukum pidana pada bagian tertentu berisi tindakan yang berkaitan dengan pelanggaran kaidah moral merupakan kesepakatan kelompok-kelompok dalam masyarakat di mana secara moral menyusun kesepakatan seluruh kelompok untuk menetapkan pemidanaan. Aliran hukum klasik melihat kejahatan adalah hasil dari perbuatan berdasarkan kebebasan moral. Kejahatan adalah produk dari kebebasan pilihan moral pihak pelanggar. Dengan mengasumsikan pada keinginan bebas yang ada, beberapa ahli teori klasik menegaskan bahwa kejahatan merupakan kesalahan dan harus bertanggungjawab secara moral, untuk itu pelanggar harus menerima hukuman yang sesuai dengan nilai moral yang hidup di masyarakat sebagai suatu tindakan pembalasan atas tindakan kejahatan yang telah dilakukannya. ${ }^{23}$

Hukum pidana dapat pula dipahami sebagai kejahatan terhadap ketertiban umum dan terdapat hukuman yang sesuai. Penuntutan dilakukan oleh institusi pemerintah yang berwenang terhadap seseorang yang telah melanggar aturan hukum tertentu. Aturan mengenai hukuman diatur lebih lanjut melalui undangundang. ${ }^{24}$ Aliran hukum pidana klasik adalah semangat pengembangan yang pada masa itu amat berpengaruh pada nilai-nilai modern dan rasional. Aliran ini berkembang dalam ilmu pengetahuan hukum terhadap kodifikasi hukum pidana. Pengaruh aliran ini terasa pada tiga asas hukum pidana klasik, salah satunya adalah

\footnotetext{
${ }^{21}$ Carl Joehim Friedrich, Filsafat Hukum Perspek.tif Historis, Terjemahan Raisul Muttaqien, Nusa Media, Bandung, 2004, hlm. 106-111.

${ }^{22}$ P.A.F. Lamintang, Hukum Penitensier Indonesia, CV. Armieo, Bandung, 1984, hlm. 23-25. Kodifikasi hukum pidana pada masa klasik, adalah berisi hal-hal yang essensial dalam hukum yang selalu dijelaskan atau dikaji lebih jauh oleh ilmu pengetahuan hukum. Hal ini terjadi karena pada masa itu kodifikasi hukum pidana disusun sedemikian rupa sehingga tidak bertentangan dengan kenyataan sosial.

${ }^{23}$ Paul W. Tappen, Juvenile Deliguency, Mc. Graw Hill Book Company Inc, New York 1949, hlm. 30.

${ }^{24}$ Henry J. Abraham, The Judicial Process: An Introductory Analysis of The Courts of The United States, England and France, Third Edition, Oxford University Press, New York, 1975, hlm. 22.
} 
asas legalitas yang berarti bahwa negara berkewajiban untuk menjelaskan perbuatan mana saja yang dapat dipidana. Ajaran yang memisahkan antara moral dan hukum dijadikan sebagai alasan untuk mengeluarkan bentuk kejahatan tradisional yang bersifat religious. ${ }^{25}$

Dari kodifikasi hukum pidana modern, Durkheim menyatakan bahwa dalam masa modernisasi, delik terhadap agama kehilangan nilainya sebagai suatu kejahatan, tetapi hanya dapat dipandang sebagai suatu perbuatan yang dapat membahayakan kepentingan individu tertentu saja. Perbedaan antara hukum dan moral tidak dapat mengaburkan perhatian dari hubungan yang terjadi antara moral sosial dan norma-norma yang terkandung di dalam kodifikasi hukum pidana klasik. Sehubungan dengan itu, Hayman Gross mengemukakan bahwa crime is morally wrong, and punishment for it is morally right. ${ }^{26}$ Kejahatan secara moral merupakan hal yang salah, dan pemidanaan untuk setiap kejahatan merupakan suatu hal benar secara moral. Pemidanaan merupakan hal yang benar dapat dipahami dalam dua arti. Pemidanaan mendapatkan pembenaran dalam praktik-praktik sosial, dapat pula berarti bahwa kegagalan untuk menghukum suatu kejahatan merupakan suatu kesalahan dan bahwa masyarakat yang tidak menghukum para penjahatnya merupakan masyarakat yang telah meninggalkan kewajiban moralnya. ${ }^{27}$

Asas mens rea atau asas kesalahan individu yang menyebabkan tidak seorang pun dapat dipidana untuk hal-hal yang tidak dikehendaki. Asas keseimbangan dalam pemidanaan berarti bahwa sanksi pidana harus dijatuhkan secara proporsional, pemidanaan terhadap delik tidak boleh berlebihan. Sanksi pidana diberikan oleh tata hukum, dari perbuatan tertentu yang dikehendaki oleh pembuat undang-undang, sehingga sanksi memiliki karakter memaksa. Pada mulanya hanya ada sanksi pidana, kemudian sanksi lain seperti perdata, ganti kerugian sebagai akibat perbuatan melawan hukum. Hukum perdata tumbuh di samping hukum pidana. Jika sanksi hukum pidana ditujukan kepada retribusi atau pencegahan, maka sanksi perdata ditujukan kepada ganti rugi. ${ }^{28}$ Semua undang-undang atau hukum positif harus diumumkan, sehingga semua warga negara mengetahuinya. Suatu hukuman yang diberikan yang penting bukan kerasnya, tetapi ketegasan,

${ }^{25}$ Hans Kelsen, Teori Umum Hukum dan Negara. Dasar-Dasar Ilmu Hukum NormatifSebagai Ilmu Hukum DeskriptifEmpiri, Op. Cit., hlm. 16-20.

${ }^{26}$ Hyman Gross, A Theory of Criminal Justice, Oxford University Press, New York, 1979, hlm. 13.

${ }^{27}$ Ibid.

${ }^{28}$ Hans Kelsen, Op. Cit., hlm. 61-62. 
ketepatan, dan mempunyai efek preventif. Penggunaan pidana penjara harus lebih banyak dan penjara-penjara harus diperbaiki. Konsep keadilan menurut aliran klasik adalah suatu hukum yang pasti untuk perbuatan-perbuatan yang sama tanpa memperhatikan sifat dari si pembuat dan tanpa memperhatikan peristiwa-peristiwa tertentu yang memaksa terjadinya perbuatan-perbuatan tersebut. ${ }^{29}$ Menurut aliran klasik, manusia itu dapat dikatakan sama dan setelah manusia itu diketahui tidaklah perlu untuk dipelajari secara tersendiri menurut kejadian demi kejadian. Dengan ini diketahui bahwa aliran klasik itu hampir tidak pernah menyebut tentang diri pembuat, walaupun masih memerlukan tempat kepadanya dalam hukum pidana. ${ }^{30}$ Menurut pandangan klasik, penguasa tidak boleh terlalu banyak mencampuri kehidupan pribadi warganya. Ahli hukum pidana klasik memberikan tempat utama kepada manusia dalam arti abstrak. Mereka tidak banyak mengadakan penyelidikan mengenai penjahat secara individual. Pikiran Beccaria dan Lambroso masih berpengaruh dalam hukum pidana masa kini, pikiran-pikiran yang senantiasa mempunyai pengaruh terhadap ahli hukum pidana, baik dalam praktik maupun teori. ${ }^{31}$

Tokoh lain dari aliran klasik adalah Jeremy Bentham (1745-1832). Idenya adalah kebaikan yang terbesar harus untuk jumlah orang yang terbesar. Manusia merupakan ciptaan, makhluk yang rasional memilih secara sadar kesenangan dan menghindari kesusahan. Oleh karenanya suatu pidana harus ditetapkan pada setiap kejahatan sedemikian rupa sehingga kesusahan akan lebih berat daripada kesenangan yang ditimbulkan oleh kejahatan. ${ }^{32}$ Bentham membagi empat antara penderitaan dan kesenangan, yang berhubungan dengan sanksi hukum yakni; penderitaan dan kesenangan fisik, moral, politis dan religius. Oleh karenanya sanksi yang dibedakan kesenangan dan penderitaan yang mungkin diharapkan secara wajar tanpa intervensi manusia menghasilkan sanksi alamiah. Selanjutnya sanksi moral adalah kesenangan dan penderitaan, yang diakibatkan oleh tindakan sesama manusia. Kesenangan dan penderitaan dari tindakan penegak hukum, berdasarkan hukum yang berlaku atau disebut sebagai sanksi politis, serta kesenangan dan

${ }^{29}$ Purniati dan Moh. Kamal Darmawan, Mą̧ab dan Penggolongan Teori dalam Kriminologi, Citra Aditya Bakti, Bandung, 1994, hlm. 47- 48.

${ }^{30}$ Roeslan Saleh, Dari Lembaran, Op. Cit., hlm. 92.

${ }^{31}$ Roeslan Saleh, Hukum Pidana sebagai Konfrontasi Manusia dan Manusia, Ghalia Indonesia, Jakarta, 1983, hlm. $33-34$.

${ }^{32}$ Muladi dan Barda Nawawi Arief, Teori-Teori dan Kebijakan Hukum Pidana, Alumni, Bandung, 1992, hlm. 31. 
penderitaan yang berdasarkan pada orientasi keagamaan, disebut sebagai sanksi pidana. ${ }^{33}$ Pada masa aliran klasik lahir KUHP Perancis (1791) yang banyak dipengaruhi oleh pikiran Beccaria. Dalam praktiknya, code penal Perancis perlu perubahan-perubahan terutama pengaruh aliran neo classical school. Aliran klasik yang tumbuh sebagai reaksi ancient regime yang arbiter pada abad kedelapan belas di Perancis. Selanjutnya aliran ini sangat mewarnai KUHP Belanda pada saat pembentukannya, sebagai pengaruh KUHP Perancis, tentunya dengan beberapa modifikasi sebagai akibat pengaruh aliran modern. Hukum pidana dalam kerangka aliran klasik disebut daadstrafrecht atau tatsstrafrecht yakni hukum pidana yang berorientasi pada perbuatan (offense oriented). ${ }^{34}$

\section{Aliran Neo Klasik Peranannya terhadap Perkembangan Pemidanaan}

M. P Rossi (1787-1844) dengan memperhatikan keadaan individu maupun masyarakat, melalui teori absolut, maupun aliran klasik, yang mencirikan penerapan hukum pidana sejalan undang-undang, metode, asumsi, posisi pidana adalah tetap. Pandangan ini, mengawali era hukum pidana neo-klasik. Penjatuhan pidana, terutama penerapan pembalasan adalah menjalankan keadilan. Hidup dalam masyarakat yang tidak sempurna, sehingga tidak mungkin untuk menuntut keadilan yang absolut. Pemidanaan dilandaskan pada tertib sosial dan etika yang tidak sempurna. Penerapan hukum pidana yang manusiawi dibatasi oleh syarat-syarat yang dituntut oleh masyarakat. Oleh karenanya, hakim diberi kebebasan yang luas dalam menjatuhkan pidana. Pembalasan dalam hukum pidana tidak boleh melampaui apa yang selayaknya diterima oleh pelaku kejahatan. ${ }^{35}$ Ciri khas dari aliran Neo Klasik adalah adanya pelunakan atau perubahan pada doktrin kehendak bebas. Kebebasan kehendak untuk memilih dapat dipengaruhi patologi (ketidakmampuan untuk bertindak), premeditasi (niat yang dijadikan ukuran kebebasan kehendak), pengakuan tentang situasi, lingkungan, dan keadaan mental individu. Perubahan doktrin tanggung jawab sempurna, menjadi tanggung jawab

\footnotetext{
${ }^{33}$ Jeremy Bentham, Teori Perundang-Undangan, Prinsip-Prinsip Legislasi Hukum Perdata dan Hukum Pidana, Terjemahan: Nurhadi, Nusamedia Nuansa, Bandung, 2006, hlm. 4-6.

${ }^{34}$ Muladi, Demokratisasi, Hak. Asasi Manusia dan Reformasi Hukum di Indonesia, The Habibie Center, Jakarta, 2002, hlm. 253. a).definisi hukum kejahatan; b). bentuk hukuman sesuai dengan kejahatannya; c). doktrin kehendak bebas; d). hukuman mati untuk beberapa pelanggaran; e). metode anekdotal tanpa penelitian empiris research; f). pemberian hukuman yang pasti.

${ }^{35}$ Jan Remmelink, Op. Cit., hlm. 611-612.
} 
sebagian, seperti kegilaan, kedunguan, usia, juga dimasukkannya persaksian, dan keterangan ahli di dalam acara pengadilan untuk menentukan besarnya tanggung jawab terhadap terdakwa, untuk mampu memilih antara benar dan yang salah. ${ }^{36}$ Aliran Neo Klasik, berkembang bersamaan dengan aliran modern dan berdasarkan pada doctrine of free will. Aliran ini juga memperhatikan perbuatan maupun pelaku (offence-offender oriented) sebagai karakteristiknya. ${ }^{37}$ Pandangan baru dalam perkembangan hukum pidana, menempatkan hukum pidana sebagai suatu alat untuk melindungi masyarakat, dari para pembuat delik. Persoalan yang utama berkembang ialah bagaimana melakukan pembaharuan hukum pidana, sehingga tercapai suatu pola baru dalam pembinaan terhadap narapidana. Dengan itu diharapkan hukum pidana menjadi lebih efektif sebagai salah satu sarana untuk mewujudkan perlindungan sosial. Perkembangan ilmu kemasyarakatan telah juga turut mengembangkan kriminologi yang objek penelitiannya adalah tingkah laku orang perseorangan dan atau masyarakat. Pengaruh kriminologi sebagai bagian dari perubahan sosial menimbulkan aliran baru yang menganggap tujuan hukum pidana adalah untuk memberantas kejahatan agar terlindungi kepentingan hukum masyarakat, disebut juga suatu mazhab modern (modern school). Pendekatan ini dikenal sebagai aliran modern ${ }^{38}$ atau kriminologi dengan suatu ciri khas individualisasi pemidanaan.

\section{Posisi Aliran Modern dalam Pemidanaan}

Aliran modern yang timbul pada abad kesembilan belas, dan yang menjadi pusat perhatiannya adalah si pembuat delik (offender oriented) atau disebut juga aliran positif karena dalam mencari sebab kejahatan menggunakan metode ilmu alam dan bermaksud untuk langsung mendekati dan mempengaruhi penjahat secara positif sejauh masih dapat diperbaiki. Karakteristik aliran modern ${ }^{39}$ menyatakan bahwa perbuatan seseorang tidak dapat dilihat secara abstrak dari sudut yuridis sematamata, tetapi juga harus dilihat secara konkrit. Dalam kenyataannya perbuatan seseorang, dipengaruhi oleh watak pribadinya, faktor biologis dan, lingkungan masyarakatnya. Aliran ini berpandangan pada pangkal tolak determinisme, karena

\footnotetext{
${ }^{36}$ Purniati dan M.Kamal, Op. Cit., hlm. 50.

${ }^{37}$ Muladi, Demokratisasi, Hake Asasi Manusia dan Reformasi Hukum di Indonesia, Op. Cit., hlm. 253-254

${ }^{38}$ Jan Remmelink, Op. Cit., hlm 33.

${ }^{39}$ Muladi, Op. Cit., hlm. 253.
} 
manusia dipandang tidak bebas berkehendak dan dipengaruhi oleh watak dan lingkungan. Oleh karena itu, manusia tidak dapat dipersalahkan atau dipertanggungjawabkan dan dipidana. Aliran ini mengubah pandangan adanya pembalasan berdasarkan kesalahan yang subjektif. Aliran modern dengan senjata ilmu pengetahuan dengan berbagai karakteristiknya (kejahatan natural, hukuman yang tidak pasti, doktrin determinisme, bentuk hukuman harus sesuai dengan kejahatan yang dilakukan, adanya diskresi yudisial, daderstrafrecht, medical model, hukuman dan perlakuan yang individual, dan sanksi yang bersifat mendidik) menunjukkan pula kelemahan, yakni terlalu memanjakan penjahat dan apabila diterapkan sungguh-sungguh terlalu mahal. ${ }^{40}$

Pelopor aliran modern adalah Lombroso, Lasagne, dan Ferri. Pada 1888, mereka mempelopori berdirinya International Union of Penal Law. Lembaga ini mengembangkan gagasan yang melihat kejahatan sebagai suatu ancaman sosial dan mencoba untuk memecahkannya dengan bantuan the new science of criminology. Pusat perhatian dari aliran ini adalah pembuat delik, dengan perlindungan sosial, perlindungan pengamanan masyarakat. Aliran ini mempelopori penggunaan metode ilmu alam dan ilmu sosial dalam mencari penyebab kejahatan. Salah satu perhatian dari hukum pidana modern adalah perhatian yang lebih dikhususkan kepada diri pembuat delik, dengan itu maka dimulailah gerakan-gerakan aliran modern. Lombroso memberi judul bukunya L'uamo Deliquento, buku inilah yang mencanangkan aliran baru. Gejala itu tidak hanya mempunyai arti teoritis, tetapi dalam praktiknya pembuat undangundang lebih banyak memperhatikan diri kepada pembuat delik. ${ }^{41}$ Sasaran aliran klasik adalah untuk menata pelaksanaan peradilan pidana melalui usaha untuk memperlunak kekuasaan penguasa.

Adapun aliran modern dibentuk untuk membuat kekuasaan tersebut lebih efektif dan merumuskan suatu teori sekuler terhadap kejahatan yang bertentangan dengan berbagai kepentingan. Peters menyebutkan sebagai suatu ideologi yang melebihi segala-segalanya. ${ }^{42}$ Aliran klasik yang menitikberatkan kodifikasi hukum pidana sebagai alat untuk melindungi kepentingan-kepentingan penguasa. Pergeseran perhatian dalam perkembangan hukum pidana melalui aliran modern

\footnotetext{
${ }^{40}$ Muladi, Kapita Selekta Sistem Peradilan Pidana, BP.Undip, Semarang, 1995, hlm. 52.

${ }^{41}$ Roeslan Saleh, Dari Lembaran, Op. Cit., hlm. 89-90.

${ }^{42}$ Peters, Op. Cit., hlm. 27. Aliran Modern dalam mempelajari hukum berkecenderungan dogmatisme dan konservatisme, bahwa hakim sebenarnya dapat mengikuti cara kerja ahli medis dalam menentukan putusan pemidanaan terhadap terdakwa.
} 
yakni memfokuskan pada kepentingan-kepentingan para pembuat delik, bahwa kejahatan dapat dicegah dengan baik melalui kepastian dan bukan melalui kerasnya hukuman yang diberikan. ${ }^{43}$

Aliran modern memecahkan kebekuan di mana tingkah laku manusia tidak lagi dibiarkan dan dikuasai oleh pemikiran-pemikiran abstrak mengenai hukum. Perkembangan kriminologi menyebabkan perubahan terhadap perkembangan modern, walaupun terjadi penyangkalan karena antara kriminologi dan hukum pidana telah lebih bersifat mengindividualisasi. Di negara tertentu hakim dapat menyatakan bersalahnya terdakwa tanpa dijatuhkan hukuman. Pandangan hukum pidana modern telah mengarah kepada sikap membuka kemungkinan berdasarkan undang-undang yang ada untuk menyatakan kesalahan tanpa diterapkan sanksi pidana kepadanya. Keyakinan seperti ini semakin tumbuh. ${ }^{44}$ Aliran modern menitikberatkan perhatiannya kepada orang yang melakukan tindak pidana dan pemberian pidana antara tindakan yang dimaksud untuk melindungi masyarakat terhadap bahaya yang ditimbulkan oleh pembuat. Dalam aliran modern kebebasan pembentuk undang-undang untuk menentukan jenis pidana, ukuran pidana, dan cara pelaksanaan pidana (strafsoert, strafmaat, dan strafmodus). Apakah seseorang dimasukkan ke dalam penjara atau diserahkan kepada probation service untuk diberi bentuk pemidanaan atau pengawasan ringan memperhatikan akibat perbuatan pelaku terhadap masyarakat, menjadi ukuran penting dalam pengambilan keputusan di peradilan pidana. ${ }^{45}$

Aliran modern, pada masanya mempengaruhi perkembangan hukum pidana dan diakui juga sebagai suatu kepercayaan yang bersifat universal, yaitu pemahaman ilmiah yang menguasai dunia kejahatan para penjahatnya. Masih dapat dicatat di sini aliran-aliran lain seperti aliran perlindungan masyarakat, aliran perlindungan masyarakat baru dari Mazhab Utrecht yang menganggap kejahatan sebagai suatu gejala manusiawi dan pernyataan seluruh kepribadian pelaku, sesudah diadili kemudian dipidana atau diperbaiki, selanjutnya harus dipupuk dan dikembangkan, kepada para penjahat. Aliran perlindungan masyarakat ingin memberikan kekuatan mengekang diri sendiri dan memupuk perasaan tanggung jawab penjahat. ${ }^{46}$

\footnotetext{
${ }^{43}$ George Goldwin, Criminal Man, George Braziller Inc, New York, 1957, hlm. 79.

${ }^{44}$ Roeslan Saleh, Segi Lain Hukum Pidana, Ghalia Indonesia, Jakarta, 1984, hlm. 20.

${ }^{45}$ Karl Menninger, “Love Against Hate,” dalam Stanley E. Grupp ed, Theories of Punishment, Indiana University Press, London, 1977, hlm. 250.

${ }^{46}$ Muladi, Demokrasi dan Hak. Asasi Manusia, Op. Cit., hlm. 254.
} 


\section{Aliran Kontrol Sosial dan Pemidanaan Humanistis}

Aliran ini, semula adalah bagian dari pandangan Prins, setelah perang dunia ke dua. Dikembangkan lebih lanjut oleh Marc Ancel, yang kemudian menstimulasi Defence Sosiale Nouvelle. Pemikiran yang berkembang dalam konteks aliran ini, dengan memperhatikan kritikan yang diajukannya terhadap ajaran lama, sesungguhnya sebagai face lift dari ajaran yang lama. Aliran ini memandang tujuan hukum pidana dalam konteks melindungi tatanan masyarakat, sekalipun mereka memberikan tekanan pada resosialisasi pemasyarakatan, dan perlunya metode penegakan hukum pidana, yang tidak sepenuhnya juridis-formil, namun sebaliknya lebih bernuansa sosial. Pentingnya individualisasi dalam pemidanaan, sehingga fokusnya pada manusia, sebagai makhluk sosial, dalam mempertanggungjawabkan perbuatannya. ${ }^{47}$ Dalam aliran kontrol sosial, hukum pidana mengalami perkembangan baru, yang ditandai dengan berbagai macam perhatian, khususnya pada abad terakhir memasuki milenium berikutnya dari zaman baru. Pemahaman terhadap hukum pidana pada abad ini tidak lagi berpangkal tolak pada hukum pidana saja, namun lebih jauh meliputi perhatian yang mengglobal, terhadap perubahan-perubahan yang terjadi akan berpengaruh pula terhadap gejala-gejala kejahatan, sehingga mempengaruhi pula cara kerja hukum pidana dalam hal menangani atau menanggulangi kejahatan. Perkembangan teknologi kerap kali membawa dampak yang paling pesat terhadap perkembangan hukum pidana, bahwa dalam banyak segi perkembangan hukum adalah karena perkembangan teknologi". ${ }^{48}$ Dengan kemajuan teknologi yang semakin pesat mendorong pula lahirnya kejahatan-kejahatan profesional dengan cara yang semakin mudah, misalnya pemalsuan uang sebagai suatu kejahatan tradisional menjadi lebih mudah dilakukan setelah ditemukannya lasser scanner oleh Quick Response Multicolor Printers pada 1980-an, yang dapat membuat warna hijau uang kertas dollar Amerika Serikat. ${ }^{49}$

Adanya fenomena kejahatan sangat berkaitan erat dengan terjadinya dipersonalisasi kehidupan dan keterasingan individu-individu tertentu, akibat adanya komputerisasi, komersialisasi dan internasionalisasi di berbagai sektor perdagangan dan industri sebagai penyebab terjadinya peningkatan angka

\footnotetext{
${ }^{47}$ Jan Remmelink, Op. Cit, hlm. 614-615.

${ }^{48}$ Roeslan Saleh, Hukum Informatika, Fakultas Hukum Universitas Muhamadiyah Jakarta, Jakarta 1996, hlm. 30.

${ }^{49}$ Michael Levi, Regulating Fraud: White Collar Crime and Criminal Justice, Tavistock Publications, London, 1987, hlm. 2 .
} 
pengangguran yang luar biasa. Hal inilah yang menyebabkan ketidakserasian di antara pribadi-pribadi dengan sistim sosial yang ada. ${ }^{50}$ Dengan adanya perubahanperubahan yang terjadi dalam masyarakat akibat globalisasi, maka mengharuskan pula pengkajian-pengkajian ulang terhadap cara bekerjanya hukum. Hal ini bertujuan agar penegakan hukum pidana dapat diimbangi dengan perhitunganperhitungan yang menyeluruh, sehingga dapat terlihat keuntungan dan kerugian dalam menggunakan sistem pidana. Globalisasi yang terjadi di bidang ekonomi melahirkan organisasi kriminal dengan jaringan global, infrastuktur, komunikasi dan hubungan hubungan internasional dalam kegiatan kejahatannya. Hubungan melalui jaringan internasional ini, memungkinkannya untuk membuka pasar-pasar baru untuk barang dan jasa ilegal, melalui perusahaan-perusahaan transnasional, melahirkan organisasi kriminal mempergunakan high-speed modems and encerypted faxes. ${ }^{51}$ Sejumlah strategi yang pada dasarnya persuasif dan pencegahan, seperti strategi pemberian nasehat dan pendidikan hukum, peringatan, sanksi administratif, perdamaian di luar pengadilan, serta negosiasi tentang penggantian kerugian. ${ }^{52}$ Terjadinya perubahan-perubahan di berbagai bidang itu sesungguhnya juga adalah akibat perkembangan dari proses masyarakat yang liberal menuju proses masyarakat berkesejahteraan.

Oleh karenanya masalah kejahatan pada mulanya adalah masalah utama dari hukum pidana menjadi bergeser dan menjadi perhatian pula bagi masalah dari negara kesejahteraan. Dalam hal penanganan kejahatan di mana tidak lagi sematamata urusan hukum pidana, tetapi harus selalu dikaitkan dengan penanganan terhadap masalah-masalah sosial. Dalam negara kesejahteraan di mana hukum pidana tidak hanya sebagai kekuatan moral di dalam masyarakat semata-mata, tetapi juga bagian menyeluruh dari suatu alat pertahanan sosial (social defence). Upaya tersebut merupakan penanggulangan kejahatan yang pada hakekatnya merupakan bagian integral dari upaya perlindungan sosial..$^{53}$ Penanganan masalah kejahatan harus dapat dikaitkan dengan perhatian terhadap kehidupan keluarga, penyelenggaraan pendidikan, aktivitas pemuda, tenaga kerja, kesehatan dan

\footnotetext{
${ }^{50}$ Constantin Kelk, Criminal Justice in The Netherlands, dalam Phil Fennel ed. Criminal Justice in Europe: A Comparative Study, Clarendon Press, London, 1995, hlm. 5.

${ }^{51}$ Mardjono Reksodiputro, "Multikulturalisme dan Negara-Negara Nation serta Kejahatan Transnasional dan Hukum Pidana Internasional.” Disampaikan dalam Seminar Nasional Pengarub Globalisasi terhadap Hukum Pidana dan Kriminologi Menghadapi Kejahatan Transnasional, Bandung, 17 Maret 2008, hlm. 1-8.

${ }^{52}$ Hazel Croal, White Collar Crime, Open University Press, Buckingham, 1992, hlm. 78.

${ }^{53}$ Barda Nawawi Arief, Bunga Rampai Kebijakan Hukum Pidana, Citra Adytia Bakti, Bandung, 2003, hlm. 2.
} 
penataan kependudukan. ${ }^{54}$ Penanganan kejahatan harus dibarengi pula dengan penanganan di bidang sosial lainnya. Ada pandangan yang sering dilupakan orang adalah seolah-olah terjadi pemisahan yang absolut antara penegakan hukum pidana, penegakan hukum administrasi, dan penegakan hukum perdata. Padahal dilihat dari sistem hukum nasional, ketiga-tiganya mempunyai kedudukan sebagai subsistem yang membawa konsekuensi tidak boleh bertentangan satu sama lain bahkan harus saling mendukung. ${ }^{55}$ Hukum pidana telah bergeser fungsinya dengan berbagai macam penyesuaian-penyesuaian, yakni menjadi salah satu bagian antara bagian lain dari kontrol sosial, sehingga membawa dampak yang luas terhadap pelaksanaan peradilan pidana itu sendiri.

Dengan demikian, hal itu membawa pula semangat terhadap tujuan peradilan pidana, sehingga menjadikan hukum pidana menjadi bagian atau perhatian serius dari kebijakan sosial dan akhirnya berkembang pandangan-pandangan tentang kebijakan pidana serta politik kriminal yang merupakan keseluruhan dari tanggapan yang rasional terhadap kejahatan, bahwa politik kriminal sebagai organisasi pengendalian kejahatan sebenarnya dilakukan oleh masyarakat. ${ }^{56}$ Hukum pidana yang oleh para ahli telah dicarikan alternatif lain yakni hukum tindakan dan usahausaha itu mulai diwujudkan melalui defence sociale nouvelle. Pemukanya adalah Marc Ancel. Gerakan ini tumbuh setelah perang dunia kedua. Pada 1945 pikiran orang terhadap kebebasan manusia dan pertanggungjawaban manusia memang berubah dari sebelumnya terutama ahli kriminologi dari Italia. Gramatika mendirikan suatu gerakan yang dinamakan Ia defence sociale. Gerakan ini mendapatkan perhatian oleh Marc Ancel dan para ahli lainnya yang menyarankan agar bersikap menahan diri di samping teliti dalam menggunakan hukum pidana. ${ }^{57}$ Pandangan aliran kontrol sosial, yang berbeda dengan aliran klasik di mana perhatian pada rumusan perbuatan pidana yang dilarang dalam kodifikasi hukum pidana dan aliran modern ditikberatkan pada perbuatan individual dari pembuat delik serta diarahkan pada pembinaan terhadap pembuat delik tersebut. Dengan demikian, aliran kontrol sosial menitikberatkan pada pembentukan sistem sanksi terhadap kejahatan, dan pemidanaan yang merupakan instrumen kebijakan, perencanaan dan organisasi.

\footnotetext{
${ }^{54}$ John Graham, Crime Prevention Strategies in Europe and North America, Helsinki Institute for Crime Prevention and Control Affiliated Eight the United Nations, Helsinki, 1990, hlm. 18-60.

${ }^{55}$ Muladi, Kapita Selekta Sistem Peradilan Pidana. Op. Cit., hlm. 41. hlm. 209

${ }^{56}$ Marc Ancel, Social Defence: A Modern Approach to Criminal Problem, Routige and Paul Kegan, London, 1965,

${ }^{57}$ Roeslan Saleh, Dari Lembaran Kepustakaan Hukum Pidana, Sinar Grafika, Jakarta, 1988, hlm. 37-39.
} 
Hal ini dapat dikenali dengan adanya berbagai ciri tertentu yakni adanya pendekatan terpadu terhadap pelaksanaan sistem peradilan pidana, yaitu dengan berperannya para pembentuk hukum dan para penegak hukum, berperan seperti dalam suatu perusahaan dan departemen pemerintahan pusat dan lokal. Pencegahan kejahatan melibatkan berbagai agen penegakan hukum yang berada di luar sistem peradilan pidana. $^{58}$

Aliran kontrol sosial mempunyai ciri khas yang menonjol yakni pertama, adanya pendekatan terpadu terhadap pelaksanaan terpadu pelaksanaan sistem peradilan pidana. Kedua, bahwa hukum pidana dilihat hanya sebagai salah satu bagian dari bentuk alternatif kontrol sosial. Ketiga, pendekatan yang dilakukan dengan cara yang amat efisien. Hukum pidana menurut aliran modern adalah sebagai satu sarana untuk mencapai tujuan perlindungan sosial. Aliran kontrol sosial hukum pidana tidak hanya menentukan apakah yang dapat di pidana, dan bagaimanakah hal itu dilakukan, namun menentukan pula siapakah yang secara formal berwenang dalam penegakan hukum itu. Oleh karenanya menjadi salah satu aliran pilar utama tentang diskresi atau kebebasan untuk diperhatikan dan terus-menerus ditingkatkan penggunaannya. Dalam hal ini amat berbeda dengan aliran modern. Dalam aliran kontrol sosial, posisi lembaga untuk menerapkan hukum menjadi lebih bebas dan diskresi semakin berkembang. Para hakim dapat melakukan definisi hukum melalui penemuan hukum yang selama ini menjadi garapan pembentuk undang-undang. Dengan peranannya yang baru tentang hukum pidana yang merupakan bagian dari kebijakan sosial, sehingga hukum pidana harus dikonstruksi ulang sebagai suatu bentuk sarana yang berisi aturan-aturan dalam mewujudkan kesejahteraan sosial. Akibat dari itu, maka akan menimbulkan berbagai dampak sosial, yaitu hukum pidana menjadi suatu masalah kehendak yang berisi tentang kebijakan mengenai aturan-aturan untuk menyeleksi penegak hukum yang dapat dilakukan pada akhirnya membawa pula pada masalah-masalah kebijakan. ${ }^{59}$

Reaksi terhadap perbuatan anti sosial dalam aliran kontrol sosial justru dipusatkan pada konsepsi pertanggungjawaban moral secara murni, berbeda pula dengan positivisme yang mengartikannya sebagai pertanggungjawaban menurut hukum atau pertanggungjawaban objektif. Pertanggungjawaban pribadi menekankan pada perasaan kewajiban moral pada diri individu dan oleh karena

\footnotetext{
${ }^{58}$ John Graham, Op. Cit., hlm. 7.

${ }^{59}$ Ibid., hlm. 7.
} 
itu mencoba untuk merangsang ide tanggung jawab atau kewajiban sosial terhadap anggota masyarakat yang lain dan juga mendorong untuk menyadari moralitas sosial. ${ }^{60}$ Konsep hukum pidana menurut aliran kontrol sosial, yakni masalah moralitas mengalami suatu perubahan-perubahan secara cepat, sehingga mempunyai dampak pula dalam kenyataan praktiknya, sebagai contoh peningkatan yang terus-menerus dalam pengaturan hukum pidana yang tentunya berdampak pula terhadap sistem lainnya. Hal lain yang dapat dilihat dari aliran kontrol sosial ini adalah terjadinya pengawasan di antara anggota masyarakat. Bila diperhatikan hal ini menjadi suatu pengawasan dengan menggunakan hukum pidana, sehingga akan berwujud dalam suatu pertanggungjawaban individual. Aliran kontrol sosial membawa suatu perkembangan baru dalam hukum pidana, yang hingga kini telah banyak menguasai prinsip-prinsip dalam sistem peradilan pidana dan pelaksanaan praktiknya. ${ }^{61}$

Pembaharuan hukum pidana, dimulai sejak UU No. 1 Tahun 1946, tentang Kitab Undang Undang Hukum Pidana, dengan pelbagai penyesuaian alam kemerdekaan. Maka ketika itulah dimulai beberapa hal, mengenai kriminalisasi, serta berkembangnya hukum pidana di luar KUHP, maupun penggunaan hukum pidana dalam undang-undang administratif.

\section{Penutup}

Beberapa aliran hukum pidana terutama aliran klasik telah membuka jalan dan menghasilkan suatu konsep hukum pidana yang lengkap dengan kodifikasi hukum pidana yang tidak bertentangan dengan kenyataan sosial pada masa itu yang dipengaruhi oleh perkembangan liberalisme dan hukum alam yang berkembang pada masanya. Aliran hukum tersebut juga menghasilkan KUHP Perancis dan Belanda dan pengaruhnya hingga kini terhadap KUHP Indonesia yang berorientasi pada perbuatan. Dilanjutkan dengan aliran neo klasik yang menitikberatkan pada perubahan doktrin kehendak bebas untuk memilih dan dipilih dan hukum pidana telah memperhatikan perbuatan maupun pelakunya. Bersamaan dengan itu aliran modern atau disebut juga sebagai aliran positif, karena mencari kejahatan menggunakan metode ilmu alam sehingga perbuatan pelaku kejahatan tidak dilihat

\footnotetext{
${ }^{60}$ Barda Nawawi Arief, Bunga Rampai Kebijakan Hukum Pidana, Op. Cit., hlm. 43.

${ }^{61}$ JS. Roucek ed, Social Control, D. Van Nostand Company Inc, Pricenton, 1962, hlm. 3.
} 
secara abstrak tetapi harus dilihat secara konkrit. Aliran ini tumbuh dan berkembang dengan perhatiannya pada pembuat delik yang belum dewasa dan model pembinaan dalam pelaksanaan pemidanaan. Perhatian yang dipusatkan pada orang yang melakukan delik. Aliran kontrol sosial, berpangkal tolak tidak hanya pada hukum pidana semata-mata, tetapi lebih jauh mengglobal terhadap perkembangan ilmu pengetahuan dan teknologi, sehingga perlu pendekatan terpadu dalam pelaksanaan sistem peradilan pidana. Untuk itu hukum pidana hanya sebagai salah satu bagian dari kontrol sosial di mana pendekatan dilakukan secara efisien dan rasional. Dengan demikian, beberapa aliran hukum pidana, yang berkembang pada masanya, telah mempengaruhi para ahli hukum pidana Indonesia, ketika merumuskan, mengaitkan landasan teori dan falsafah pemidanaan, dalam kancah pembaharuan hukum pidana, baik melalui pembaharuan perundang undangan, maupun hukum pidana formil dan materil, yang sedang dalam pembahasannya. Aliran dan falsafah pemidanaan bersikap sebagai alat potret pembaharuan hukum pidana Indonesia.

\section{Daftar Pustaka}

A.G Peters,Antonie. Main Currents In Criminal Law Theory. Dalam Jan Van Dijk ed, Criminal Law In Action; An Overview of Currecnts Issues In Western Societie, Kluwer Law and Taxation Publisher, London, 1996.

A. Hudson, Barbara, Understanding Justice: an Introduction to Ideas, Perspectives and Controversies in Modern Penal Theory, Second Edition, Open University Press, Great Britain, 2003.

Ancel, Marc, Social Defence: A Modern Approach to Criminal Problem, Routige and Paul Kegan, Pricenton, 1965.

Bakhri, Syaiful, Pidana Deda dan Korupsi, Total Media, Yogyakarta, 2009.

Beccaria, Cesare, Of Crimes an Funisments, Marsilio, Publishers, New York 1996.

Bentham, Jeremy, Teori Perundang-Undangan, Prinsip-Prinsip Legislasi Hukum Perdata dan Hukum Pidana, Terjemahan: Nurhadi, Nusamedia Nuansa, Bandung, 2006.

Croal, Hazel, White Collar Crime, Open University Press, Buckingham, 1992.

Dworkin, R.M., Filsafat Moral Sebuah Pengantar, penterjemah Yudi Santoso, Yogyakarta, 2007.

Goldwin, George, Criminal Man, George Braziller Inc, New York, 1957.

Graham, John, Crime Prevention Strategies in Europe and North America, Helsinki Institute for Crime Prevention and Control Affiliated Eight the United Nations, Helsinki, 1990. 
Gross, Hyman, A Theory of Criminal Justice, Oxford University Press, New York, 1979.

Hamzah, Andi, Sistem Pidana dan Pemidanaan dari Retribusi ke Reformasi, Pradnya Paramita, Jakarta, 1986.

Huda, Chairul, Dari Tiada Pidana Tanpa Kesalahan Menuju Kepada Pertanggungjawaban Pidana Tanpa Kesalahan, Prenata Media, Jakarta, 2006.

J. Abraham, Henry, The Judicial Process: An Introductory Analysis of the Courts of the United States, England and France, Third Edition, Oxford University Press, New York , 1975.

Joehim Friedrich, Carl, Filsafat Hukum PerspektifHistoris, Terjemahan Raisul Muttaqien, Nusa Media, Bandung, 2004.

Kelk, Constantin, Criminal Justice in the Netherlands, dalam Phil Fennel ed. Criminal Justice in Europe: A Comparative Study, Clarendon Press, London, 1995.

Lamintang, P.A.F., Hukum Penitensier Indonesia, Armico, Bandung, 1989.

Levi, Michael, Regulating Fraud: White Collar Crime and Criminal Justice, Tavistock Publications, London, 1987.

Menninger, Karl, “Love Against Hate," dalam Stanley E. Grupp ed, Theories of Punishment, Indiana University Press, London, 1977.

Muladi, Demokratisasi, Hak Asasi Manusia dan Reformasi Hukum di Indonesia, The Habibie Center, Jakarta, 2002.

Muladi dan Barda Nawawi Arief, Teori-Teori dan Kebijakan Hukum Pidana, Alumni, Bandung, 1992.

Nawawi Arief, Barda, Kebijaksanaan Legislatif Mengenai Penetapan Pidana Penjara Dalam Rangka Usaha Penanggulangan Kejahatan Kejahatan, Disertasi Doktor di Universitas Padjadjaran Bandung, 1985.

Purniati dan Moh. Kamal Darmawan, Mazhab dan Penggolongan Teori dalam Kriminologi, Citra Aditya Bakti, Bandung, 1994.

Reksodiputro, Mardjono, "Multikulturalisme dan Negara-Negara Nation serta Kejahatan Transnasional dan Hukum Pidana Internasional." Disampaikan dalam Seminar Nasional Pengaruh Globalisasi terhadap Hukum Pidana dan Kriminologi Menghadapi Kejahatan Transnasional, Bandung, 17 Maret 2008.

Remmelink, Jan, Hukum Pidana; Komentar Atas Pasal Pasal Terpenting dari KUHP Belanda dan Padanannya Dalam KUHP Indonesia, PT. Gramedia Pustaka Utama, Jakarta, 2003.

Roucek ed, JS., Social Control, D. Van Nostand Company Inc, Pricenton, 1962.

Saleh, Roeslan, Bunga Rampai Kebijakan Hukum Pidana, Citra Adytia Bakti, Bandung, 2003.

, Hukum Informatikam, Fakultas Hukum Universitas Muhamadiyah Jakarta, Jakarta, 1996.

Kapita Selekta Sistem Peradilan Pidana, BP.Undip, Semarang, 1995. 
- Pembinaan Cita Hukum dan Asas-asas Hukum Nasional, Karya Dunia Fikir, Jakarta, 1995.

, Dari Lembaran Kepustakaan Hukum Pidana, Sinar Grafika, Jakarta, 1988.

, Segi Lain Hukum Pidana, Ghalia Indonesia, Jakarta, 1984.

- Hukum Pidana sebagai Konfrontasi Manusia dan Manusia, Ghalia Indonesia, Jakarta, 1983.

, Penjabaran Pancasila dan Undang-Undang Dasar 1945 dalam Perundang-undangan, Aksara Baru, Jakarta, 1979.

Serikat Putra Jaya, Nyoman, Relevansi Hukum Pidana Adat Dalam Pembaharuan Hukum Pidana, PT. Citra Aditya Bhakti, Bandung, 2005.

Simons, Kitab Pelajaran Hukum Pidana, Terjemahan P.A.F. Lamintang, Pioneer Jaya, Bandung, 1981.

Sudarto, Hukum dan Hukum Pidana, Alumni, Bandung, 1983.

Ted Honderich, Punishment The Supposal Justifications, Penguin Book, London, 1979.

Van Bammelen, J.M., Hukum Pidana II, Bina Cipta, Bandung, 1991.

W. Tappen, Paul, Juvenile Deliguency, Mc. Graw Hill Book Company Inc, New York, 1949. 